\title{
De Schrift, het dogma en de dogmatiek
}

\author{
J Muis ${ }^{1}$ \\ Universiteit Utrecht (Nederland) \\ Navorsingsassosiaat: Universiteit van Pretoria
}

\begin{abstract}
Scripture, dogma and dogmatics

In this article it is argued that in actual systematic reflection on the Christian faith we cannot a priori assume that the dogma has the same content as Scripture, because it is strongly determined by its culturalphilosophical, its theological and its ecclesiastical-political contexts. Secondly, it is argued that the dogma is not a rule of faith or a hermeneutical rule for the interpretation of Scripture, but a grammatical rule for the use of the vocabulary of faith. Thirdly, Lindbeck's concept of truth is discussed. Lindbeck rightly maintains a notion of ontological truth as correspondence, but wrongly reduces this correspondence to correspondence between the life of the believer and God and unnecessarily restricts ontological truth to the first order propositions of faith. Doctrinal propositions can claim ontological truth too (though they don't need to do so). This criticism, however, does not affect Lindbeck's clarifying analysis of the rule-character of doctrinal propositions.
\end{abstract}

Wij preken nooit over de drie-eenheid of over de godheid van Christus. Wij spreken het Woord Gods. Het dogma moet ons echter waarschuwen als wij de weg van alle trouwe predikers verlaten. Het is de enige die slapen mag in de kerk en het wordt pas wakker als de goede prediker met Homerus even inslaapt.

(Noordmans 1979:220)

\section{DE OPGAVE VAN DE DOGMATIEK}

Moderne gelovigen hebben geen enkele behoefte aan dogmatiek. Zij denken dat de dogmatiek hun geloven eerder zal blokkeren en verstikken dan verdiepen en

\footnotetext{
${ }^{1}$ Prof dr J Muis is 'n navorsingsgenoot van prof dr J Buitendag van die Departement Dogmatiek en Christelike Etiek, Fakulteit Teologie, Universiteit van Pretoria, op die terrein van die Identiteit en Relevansie van die Kerk.
} 
stimuleren. Dit gevoelen gaat bij velen gepaard met het postmoderne besef dat de werkelijkheid van het geloof niet in één beeld is te vangen, en dat daarom zoveel mogelijk verschillende beelden en visies naast elkaar moeten bestaan. De veelheid en veelvormigheid van geloofsvisies sluit voor hun besef een dogmatische benadering uit. Zij zien de dogmatiek kennelijk als een poging om heel het geheim van de geloofsinhoud in één enkel systeem omvattend en uitputtend te verklaren.

Ook de ouderdom van het dogma is geen aanbeveling. In een recente misdaadroman wordt verteld over iemand die min of meer toevallig een kerkdienst heeft bezocht en zich verbaast zich over het credo. Wanneer hij later hoort dat de geloofsbelijdenis van Nicea dateert uit 325 neemt zijn verbazing alleen maar toe: "Why doesn't the Church bring it up to date? We don't look to the fourth century for our understanding of medicine or science or the nature of the universe. I don't look to the fourth century when I run my companies. Why look to 325 for our understanding of God?" (James 2002:28).

Tegen de achtergrond van deze gevoeligheden rond de dogmatiek en het dogma duid ik kort aan hoe ik de opgave van de dogmatiek zie en welke rol het dogma daarbij speelt. Dogmatiek is voor mij de systematische doordenking van de inhoud van het geloof van de christelijke gemeente. Deze doordenking vindt plaats aan de hand van de Schrift en van actuele geloofservaringen en geloofsvragen. In het zoeken van antwoorden gaan we ook te rade bij de traditie en bij het dogma. Het dogma is evenwel niet het vertrekpunt; dogmatiek is geen systematische uitwerking van het dogma. "Vorausgesetzt werden in der dogmatischen Arbeit also nicht die Dogmen, sondern das christliche Glaubensleben und die Probleme, die es aufwirft" (Dalferth 1993:308). Het dogma is ook geen eindpunt van de dogmatische reflectie; dogmatiek is geen explicatie en rechtvaardiging van het dogma. Het dogma is noch beginterm, noch eindterm, het is een middenterm. Het dogma bemiddelt, het dient de verbinding tussen Schrift en geloof en tussen geloof en Schrift. Het dogma is waardevol wanneer het deze bemiddelende functie feitelijk vervult. 
De dogmatiek richt zich op het hedendaags geloof van de gemeente in interactie met hedendaagse uitdagingen en problemen. Als systematische theologie levert zij een bijdrage aan het wetenschappelijk onderzoek naar menselijk geloven in God en spreken over God. Daarnaast kan de dogmatische reflectie, hoe theoretisch zij soms ook kan worden, een bijdrage leveren aan de praktijk van het leven voor Gods aangezicht en met de naaste. De dogmatiek helpt de gemeente om hier en nu christelijk te geloven en om christelijk te spreken over God. De dogmatiek verricht deze hulpdienst door bij het handelen en spreken van de gemeente twee vragen te stellen: is het bij de tijd en is het christelijk. De vraag naar het bij-de-tijdse van het geloof impliceert niet dat de kerk zich aan de tijdgeest moet aanpassen. Men kan ook bij de tijd zijn door de tijdgeest op goede gronden te weerspreken. Maar men kan niet geloven buiten de tijd. Het geloof is geen tijdloos gebeuren of gegeven, maar een daad van mensen die in een bepaalde tijd leven.

Het maakt in de praktijk nogal wat uit of men zijn dogmatische aandacht vooral focust op het christelijke of op het bij-de-tijdse van het geloof. Soms is de concentratie op het christelijke als zodanig het meest bij de tijd, zoals in de Duitse kerkstrijd. Maar dergelijke situaties zijn uitzonderlijk. Wie focust op het bijde-tijdse zal de tijdgeest tot zich moeten toelaten en zelf helemaal moeten doorleven. Wie focust op het christelijke zal zich allereerst met Schrift en dogma bezig houden, want die spelen hoe dan ook een belangrijke rol bij de vraag wat de term "christelijk" inhoudt en in hoeverre het hedendaags geloof van de gemeente christelijk is te noemen. Het meest inspirerend en vruchtbaar zijn theologen bij wie de aandacht voor het een op geen enkele manier op mindering komt van het andere, maar die zijn zeldzaam.

Tot nu toe heb ik argeloos gesproken over Schrift en dogma, maar het probleem is dat dit twee heel verschillende grootheden zijn, die in de dogmatische arbeid ieder een eigen rol hebben te vervullen. Hoe moeten wij hun verhouding bepalen? Ik bespreek die vraag op twee manieren. Eerst vraag ik naar de betekenis van het dogma vanuit de Schrift gezien. Vervolgens vraag ik naar het gebruik of de functie van het dogma in onze omgang met de Schrift. 
Onder dogma versta ik met Gloege (Gloege 1958: 234) globaal de fundamentele leeruitspraken van de christelijke kerk over Jezus Christus en de drie-ene God. Omdat ik het dogma in de dogmatiek vooral zie functioneren als spreekregel voor de geloofstaal, stel ik tenslotte de vraag aan de orde in hoeverre geloofsuitspraken en leeruitspraken waar kunnen zijn.

\section{SCHRIFT EN DOGMA}

Dat het dogma niet met zoveel woorden in de Schrift staat, is niet meer dan een open deur. Het dogma kan ook niet rechtstreeks uit de Schrift worden afgeleid. "Scripture is not primarily a set of premisses, from which deductions may be made. It is a specific mode of discourse and pattern of thinking, which requires transposition in an interpretative framework" (McGrath 1979:62). De spannende vraag is dus of het dogma inhoudelijk met de Schrift overeenstemt. Omdat het dogma de inhoud van het Schriftgetuigenis in een ander raamwerk en in een andere terminologie probeert uit te drukken, is deze vraag moeilijk te beantoorden. Hoe is de verhouding tussen de bedoelde inhoud, de gehanteerde begrippen en het achterliggende raamwerk? Geeft het dogma alleen een explicatie van wat impliciet in het geloof van de eerste gemeente is verondersteld, zoals de godheid van Christus en van de Geest? Doet het dogma ook een poging deze bijbelse veronderstellingen in het raam van hellenistisch denken aannemelijk, althans begrijpelijk te maken? Of gaat het dogma nog verder en levert het ook een eigen bijdrage aan het academische zoeken naar de waarheid aangaande de kosmos en het zijn; is het dogma ook een kosmologische en ontologische speculatie?

Deze vragen kunnen alleen worden beantwoord door nauwkeurig theologiehistorisch onderzoek waarin het dogma wordt geanalyseerd in de context van de filosofische cultuur, de theologische probleemstelling en de kerkelijke strijd van toen. Ik licht deze contexten kort toe om te laten zien dat deze contextualiteit ons voor ingrijpende vragen stelt. 


\subsection{De cultureel-wijsgerige context van het dogma}

Aan het hellenisme en met name de midden- en neoplatoonse filosofie ontleent het dogma termen als logos, wezen, natuur, hypostase. Omdat dit voor het Griekse gehoor bekende termen waren, konden ze worden gebruikt in de verkondiging van de kerk. Blijven dergelijke termen nu ook geschikt voor een gehoor dat deze termen niet meer van huis uit kent? Dat is niet alleen een kwestie van woordenschat. Deze termen veronderstellen ook een bepaald werkelijkheidsverstaan. Hoe verschillend de Grieken ook dachten, de meesten twijfelden er niet aan dat iets als een "onveranderlijk wezen" of een "natuur der dingen" werkelijk bestond. Maar in ons filosofisch klimaat is een dergelijk essentialisme helemaal niet meer vanzelfsprekend. Moeten wij nu omwille van het dogma filosofische essentialisten worden of blijven? Dwingt het dogma ons tot de keuze voor een bepaalde filosofie en ontologie?

Deze vragen betreffen de bruikbaarheid van de dogmatische termen in de huidige situatie. Maar we kunnen nog een stap verder gaan en de kritische vraag stellen of de keuze van deze termen in de situatie van toen wel verant-woord was. Deze termen zijn immers ontleend aan verschillende filosofieën, waarin zij een heel bepaalde, eigen betekenis hadden. In hoeverre heeft bijvoorbeeld een term als logos zijn stoïsche of neoplatoonse betekenis behouden of juist verloren in het christelijk gebruik? En waarom is juist deze term de centrale term van de christologie geworden? Zijn er geen andere? Zijn er geen betere? Is logos in het Nieuwe Testament de centrale of de belangrijkste term om de unieke eenheid tussen Jezus en God uit te drukken? En is de invulling die de term logos in het dogma heeft gekregen in overeenstemming of zelfs maar verenigbaar met "logos" in Johannes 1 ?

Dit zijn vragen waar de dogmatiek niet omheen kan. Het staat niet bij voorbaat vast, dat het dogma overeenstemt met de inhoud en de strekking van de Schrift. Dit is en blijt een punt van kritisch onderzoek en wetenschappelijke discussie. 


\subsection{De theologische context van het dogma}

Naast de filosofische achtergrond is de theologische van groot belang om het dogma te begrijpen. De ariaanse controverse bijvoorbeeld had niet alleen een neoplatoonse metafysica als achtergrond. Het geding over de ontologische status van de logos kon pas ontstaan, nadat de logoschristologie het dominante christologische model was geworden. Voordat dit gebeurde, waren diverse andere christologische modellen gangbaar die zich met evenveel recht op de Schrift konden beroepen, vormen van Geestchristologie bijvoorbeeld. Hedendaagse dogmatiek dient de voor - en nadelen van logos- en Geestchristologie tegen elkaar af te wegen. De logoschristologie kan daarbij geen vanzelfsprekend uitgangspunt zijn. Dit heeft consequenties voor de theologische waardering van de leerbeslissing van Nicea-Constantinopel. Wanneer men denkt in termen van logoschristologie en vervolgens de ontologische vraag stelt naar de verhouding tussen de logos en de Vader, dan heeft Athanasius gelijk. Wanneer wij de probleemstelling van Arius en Athanasius overnemen, dan volgen wij Athanasius. Wij kunnen deze gelding van Nicea-Constantinopel in de kerk verhelderen met behulp van de indeling van leerstukken die is ontwikkeld door $\mathrm{G} A$ Lindbeck (1984:84-88). Volgens Lindbeck zijn de leerstukken die de kerk nodig heeft, essentieel of bijkomstig; de essentiële zijn onvoorwaardelijk of voorwaardelijk; de voorwaardelijke zijn permanent of tijdelijk; de tijdelijke zijn onomkeerbaar of omkeerbaar. Nicea-Constantinopel is volgens deze indeling essentieel, maar niet onvoorwaardelijk. De voorwaarde voor de gelding van deze leeruitspraak is de probleemstelling van Arius en Athanasius in termen van de logos-christologie. Maar zijn wij aan deze probleemstelling gebonden? Zijn andere probleemstellingen in onze situatie niet relevanter en urgenter? Bijvoorbeeld het verstaan van Jezus' volle menszijn als een historisch menszijn dat zich in de tijd ontwikkelt als een echte geschiedenis. En kunnen we dan Jezus' unieke eenheid met God misschien beter uitdrukken in termen van een Geestchristologie? Is het dogma nog bruikbaar om onze problemen op te lossen, wanneer de probleemstelling achter het dogma de onze niet meer is? In de termen van Lindbeck: is de voorwaardelijke gelding van Nicea-Constantinopel permanent of tijdelijk? Alleen 
deze vragen al, nog afgezien van de antwoorden die men er op geeft, maken duidelijk dat de christologische discussie niet kan worden gereduceerd tot een eenvoudige keuze voor of tegen Athanasius.

\subsection{De kerkelijke context van het dogma}

Het dogma is ontstaan in een specifieke kerkelijke situatie. Hier is de leeruitspraak van Chalcedon een treffend voorbeeld. Dogmatische eenheid in de kerk werd een eis van de keizer toen de kerk rijkskerk was geworden. De leeruitspraak van Chalcedon was vooral een politieke noodzaak. Was het ook kerkelijke noodzaak? Dezelfde vraag kan gesteld worden naar aanleiding van de canones van Dordt. Waren de leerregels een kerkelijke, of allereerst een politieke noodzaak? De verbanning van de remonstrantse predikanten geeft te denken en is voor mij een dieptepunt in onze Nederlandse geschiedenis. Ook de nasleep van Chalcedon stemt niet vrolijk. Het dogma dat eenheid beoogde, leidde feitelijk tot kerkscheuring. Deze nageschiedenis plaatst ons onherroepelijk voor de vraag of het vastleggen van de rechte leer en van de ketterij wel een goed middel is om de geloofseenheid in de kerk te bevorderen en om met bestaande geloofsverschillen om te gaan. Is dogmatisering van het geloof en verkettering van andersgelovigen de oplossing of juist de ontkenning van het probleem? En moet deze ontkenning er niet onherroepelijk toe leiden dat andersgelovigen ten diepste als ongelovigen worden gezien? En moeten die vervolgens niet als ketters worden uitgesloten van de gemeenschap van de kerk? Maar is dergelijk kerkelijk machtsgebruik niet een ongehoorde en ongeoorloofde politisering van de gemeenschap der heiligen? Eén ding lijkt mij duidelijk: dogmatisering en politisering van het geloof gaan vaak hand in hand en maken het moeilijk, zo niet onmogelijk, om met geloofsverschillen om te gaan en andersgelovigen voluit als zuster en broeder te aanvaarden in het lichaam van Christus. Het is belangrijk de politieke belangen die een rol spelen bij het streven naar kerkelijke eenheid en het uitsluiten van andersgelovigen in de vierde, vijfde en zeventiende eeuw, op te merken. We mogen niet vergeten dat de Verlichting niet in de laatste plaats een reactie was op de godsdienstoorlogen. De huiver voor dogmatisme kan niet als 
symptoom van de postmoderne tijdgeest worden afgedaan. Het is de geschiedenis van de kerk zelf die veel mensen huiverig maakt voor dogma's en deze huiver is terecht.

\subsection{Conclusie}

Al met al moeten we vaststellen dat de weergave van de inhoud van de Schrift in het dogma sterk contextueel is bepaald. Juist in zijn context en dankzij die context heeft het dogma gewerkt. Intussen is de context van de kerk drastisch veranderd. Daarom kan het dogma als weergave van het geloof niet zonder meer worden herhaald. Wanneer we in onze context alleen de woorden van toen gebruiken, zeggen we iets anders. We zullen daarom de betekenis van het dogma als verwoording van het geloof allereerst in zijn eigen contexten moeten ontdekken, om deze vervolgens weer te geven in termen die passen in onze context. Niet herhalen, maar vertalen. Op het niveau van de verwoording van het geloof is het dogma één van de vele mogelijkheden. Dit betekent dat de praktische waarde van het dogma filosofisch, theologisch en kerkelijk beperkt is.

Hiermee ontken ik niet dat de studie van het dogma een positieve bijdrage levert aan de hedendaagse geloofsdoordenking. Wanneer we de weg van de Schrift via de traditie naar het heden nagaan, ontdekken we dat veel "nieuwe" of "moderne" opvattingen reeds zijn opgekomen, overwogen en beoordeeld. Het dogma is een goede waarschuwing tegen misvattingen en ontsporingen, omdat het mede berust op een doordachte afweging van posities en argumenten. Het is, anders dan de gangbare opvatting doet vermoeden, het tegendeel van een ondoordacht vooroordeel. Daarom is het niet wijs om het dogma als overbodige ballast overboord te zetten. "Saints and prophets are rare, and doctrinal decisions and reflections on those decisions, while poor substitutes for inspiration, are preferable to uninspired and unreflective predjudice" (Lindbeck 1984:79).

Maar heeft het dogma alleen waarde als mogelijke vertolking van het geloof? Of kan het ook op een andere manier functioneren? Dit brengt ons bij de vraag naar de betekenis van het dogma voor onze omgang met de Schrift. 


\section{DOGMA EN SCHRIFT}

Wij kunnen het dogma ook anders gebruiken dan als geloofsverwoording, namelijk als spreekregel. Het dogma zegt dan niet wat wij geloven, maar hoe wij vanuit de Schrift in het heden kunnen spreken. Nu wordt de term spreekregel door velen en in vele betekenissen gebruikt. Ik zal proberen aan te tonen dat een spreekregel iets anders is dan een geloofsregel en een leesregel. Vervolgens luidt mijn these: het dogma is niet primair geloofsregel, ook niet leesregel, maar spreekregel.

\subsection{Het dogma is geen geloofsregel}

De term regula fidei komen we in de vroege kerk vooral tegen bij Ireneaus en Tertullianus (Hauschild 1995:78; Kasper 1995:306, 309, 310; Kelly 1999:2, 7688, 206; Kelly 2000:35-48, 87-89; Loofs 1906:131-134, 747-749; Wansink 2000:34, 35). De geloofsregel is een korte samenvatting van het geloofsonderricht van de kerk. Zij geeft in enkele hoofdpunten weer wat door allen in de kerk wordt geloofd en heeft als zodanig normatieve betekenis. Opmerkelijk is dat de geloofsregel nergens in een enkele formulering schriftelijk is vastgelegd; hij hoort tot de mondelinge overlevering. De verhouding tussen de geloofsregel en de vroege belijdenissen is omstreden. Ze vallen in elk geval niet samen. Wanneer wij het dogma opvatten als geloofsregel, beschouwen wij het als normatieve weergave van wat door heel de kerk wordt geloofd en beleden. Het dogma wordt dan een waarheid die je geloven moet, wil je christen zijn.

Tegen deze opvatting kunnen twee bezwaren worden ingebracht. De eerste heb ik boven al genoemd. Een contextueel bepaalde formulering van het geloof kan in andere contexten niet eenvoudigweg worden herhaald, precies omdat de betekenis en werking van een dergelijke formulering mede van de context afhankelijk is. Men zou kunnen tegenwerpen dat dit bezwaar vervalt wanneer de contexten van toen en nu niet wezenlijk verschillen. Is dit een reële mogelijkheid? Is het denkbaar dat de culturele, theologische en kerkelijke contexten van een hedendaagse gemeente in grote trekken overeenkomen met die van de jonge kerk, zodat het dogma in die gemeente op hetzelfde niveau 
fungeert als de Schrift en de belijdenis? Ik wil die mogelijkheid niet bij voorbaat uitsluiten. Maar zelfs wanneer dat het geval zou zijn, is het dogma daarmee nog geen regula fidei geworden. Het functioneert immers alleen als geloofsverwoording in die bepaalde gemeente en niet in heel de hedendaagse kerk.

Een tweede bezwaar is dat op deze manier onvoldoende onderscheid wordt gemaakt tussen Christus als de centrale geloofsinhoud, de Schrift als primaire verkondiging, de belijdenis als antwoord van het geloof op die verkondiging en een dogma als leeruitspraak in een theologische controverse (Gloege 1958:222, 223; Lohse 1974:12-16; Noordmans 1979:173, 177, 227, 229; Ritschl 1984:111; Van Ruler 1973:91). Wij geloven in de Christus der Schriften en spreken dit geloof uit in een christelijke belijdenis, die primair functioneert in de eredienst. Dit geloof kan verder worden gepreciseerd in een normatieve leeruitspraak van de kerk, een dogma. Schrift, verkondiging, eredienst, belijdenis en dogma richten ons geloof op Christus. Dat is hun dienst en hun eer. Zij mogen echter niet de plaats van Christus innemen. Wij geloven in Christus, niet in het dogma.

\subsection{Het dogma is geen leesregel}

De geloofsregel speelt al vroeg een rol in discussies over de uitleg van de Schrift. We vinden dit niet alleen bij Irenaeus en Tertullianus, maar ook bijvoorbeeld in Augustinus' De doctrina christiana (III, ii, 3). Een goede uitleg is die, welke overeenstemt met de geloofsregel. De geloofsregel is hier leesregel geworden. Wie de Schrift uitlegt in strijd met de geloofsregel, zet zichzelf kerkelijk buiten spel. Hoe wijs het ook moge zijn de eigen individuele opvatting te toetsen aan het algemeen-kerkelijk gevoelen, principieel betekent dit dat de Schrift wordt onderworpen aan de kerkelijke traditie. Daarom kunnen wij als reformatorische christenen het dogma niet als leesregel bij de Schrift hanteren. Mogelijk kan het dogma helpen om bepaalde teksten te verhelderen en in die zin een leeshulp bieden. Zo ongeveer heeft Koopmans in zijn dissertatie de functie van het dogma als leesregel in de prediking en catechese van Calvijn beschreven (Koopmans 1955:128-130, 141-147). Ook Van Veluw noemt het dogma een leesregel omdat 
het "behulpzaam" is bij het lezen en begrijpen van bijbelteksten (Van Veluw 2002:13) Maar deze leeshulp is eerder heuristisch dan normatief. Daarom zou ik deze functie van het dogma, anders dan Koopmans en Van Veluw, liever niet aanduiden met de term leesregel. Het sola scriptura vraagt om vrije exegese.

Interessant in dit verband is een opmerking van Calvijn in de voorrede van de Institutie. Hij zegt daar dat hij de Schrift wil uileggen in de overeenstemming, de analogie van het geloof (Rom 12: 6). Uitleggen in overeenstemming met het geloof dat de Schrift wekt, wil voor Calvijn zeggen: de Schrift op zo 'n manier uitleggen dat Gods grootheid en barmhartigheid en onze kleinheid en ellende daarin aan het licht komen. Deze analogia fidei, zegt Calvijn, is onze regula fidei (Calvijn 1928:12; Opitz 1994:262-264). Wat hij hier aanduidt lijkt meer op wat Barth later "bijbelse houding" zal noemen (Barth 1960:912-919) dan op een samenvatting van geloofswaarheden. Een leesregel in de oude zin van het woord is een zo opgevatte regula fidei niet meer. Daarom lijkt het mij in lijn met de Geneefse reformator om te zeggen dat wij de Schrift erkennen als enige regel des geloofs. Ik ontleen deze formulering aan een oude vraag bij de bevestiging van predikanten: "Erkent gij de heilige Schrift als de bron der prediking en als enige regel des geloofs en verwerpt gij elke leer, die daartegen strijdt?" (Nederlandse Hervormde Kerk 1955:151, 156). De gedachte dat de Schrift geloofsregel is, vinden we overigens reeds in de Confessio Gallicana IV (1559): "Nous cognoissons ces livres estre canoniques et reigle trescertaine de nostre foy (...)" (Müller 1903:222).

\subsection{Het dogma is spreekregel}

Het dogma is geen geloofsregel die zegt wat wij geloven, ook geen leesregel die zegt wat wij in de Schrift te lezen hebben, maar spreekregel die zegt hoe wij vanuit de Schrift en in het geloof van de kerk in het heden kunnen spreken. Als spreekregel hoort het dogma tot de spraakkunst van het christelijk geloof. Regels helpen ons de woorden van het geloof goed en doeltreffend te gebruiken. De regels vormen samen met een vocabulaire de geloofstaal. Voor het spreken van de geloofstaal is het kennen van de woordenschat een eerste vereiste. De vaste 
kern van deze woordenschat bestaat uit de woorden van de Schrift waarop het geloof is gegrond. Naast deze kern zijn er de woorden van het geloof der kerk, de liederen, gebeden, formulieren, belijdenissen, de woorden van de traditie. En er is een actuele uitleg van Schrift en traditie in nieuwe, eigentijdse woorden, die zo treffend en doeltreffend kunnen zijn dat zij tot de traditie gaan behoren. Het is nodig al deze woorden van het geloof te kennen, maar dit is nog niet voldoende om zelf te kunnen spreken. Dat kun je pas als je deze woorden volgens de regels der kunst weet te gebruiken. Het kennen van regels is natuurlijk nooit een doel op zichzelf. Het gaat er om dat je de regels kunt toepassen en de geloofstaal kunt spreken.

We kunnen het dogma beschouwen en hanteren als een regel die in het spreken wordt toegepast. Of preciezer gezegd: als een standaardvoorbeeld van de toepassing van de basisregels van het christelijk spreken over God. We zouden de christologische basisregels bijvoorbeeld als volgt kunnen formuleren:

- In Jezus Christus is ons heil.

- In Jezus Christus is God zelf helemaal aanwezig.

- Jezus Christus is volledig mens.

Deze basisregels zijn reeds in het Nieuwe Testament werkzaam, ook al worden zij daar niet expliciet geformuleerd. Het oudkerkelijk dogma is een toepassing van deze regels in de theologische en filosofische context van de logoschristologie en de midden- en neoplatoonse ontologie. De basisregels worden uitgewerkt met tijdgebonden, variabele termen. Vanwege die tijdgebonden termen is het dogma als geloofsverwoording van betrekkelijke waarde. Maar als toepassing van de basisregels blijt het dogma normatief voor ons spreken over God en Christus. Ook ons eigentijdse spreken heeft de basisregels achter dit paradigma te volgen, wil het christelijk blijven. Op deze wijze beschouwd, formuleert het dogma aan welke voorwaarden christelijk spreken over God en Jezus Christus moet voldoen (Lindbeck 1984:94-96). 
Het dogma als paradigmatische concretisering van de basisregels schrijft dus niet voor wat wij in onze tijd moeten zeggen. Men kan met andere woorden de basisregels achter het dogma toepassen en hetzelfde geloof verwoorden. Het dogma is een paradigma, een voorbeeldzin. Niet wie het paradigma kan herhalen heeft de regels begrepen, maar wie de regels kan toepassen in het gebruik van andere woorden en zinnen (Lindbeck 1984:81).

Het gebruik van het dogma als spreekregel sluit het gebruik van het dogma als geloofsverwoording overigens niet uit. Met name in de doxologie kan het zo fungeren, bijvoorbeeld wanneer wij in de eredienst belijden dat het eeuwige Woord God uit God is en Licht uit licht, van hetzelfde wezen als de Vader. Deze klassieke geloofswoorden van de vroege kerk behoren tot de liturgische woordenschat van de kerk der eeuwen. Wij kunnen met deze woorden God loven zonder de ontologische bekommernissen van de vroege kerk te doorgronden of zelfs maar te beseffen. Ingrijpender is de vraag of de functie van het dogma als spreekregel zijn waarheidsaanspraak niet onmogelijk maakt.

\section{WAARHEID VOLGENS LINDBECK}

Kunnen regels waar zijn? Kunnen ware uitspraken regels zijn? Omdat ik me hierboven nauw heb aangesloten bij formuleringen van Lindbeck, wil ik tenslotte ingaan op zijn visie op de relatie tussen de regulatieve functie van het dogma en de waarheidsvraag. Ik zal proberen duidelijk te maken, dat men het dogma als spreekregel kan beschouwen zonder alle consequenties die Lindbeck daar aan verbindt voor zijn rekening te nemen.

\subsection{De visie van Lindbeck}

Leerstellige uitspraken zijn volgens Lindbeck de regels voor het taalspel van de geloofsgemeenschap. Zo beschouwd hebben leeruitspraken betrekking op geloofsuitspraken, niet op de geloofde werkelijkheid. De leer is geen eerste-orde taal over een buitentalige werkelijkheid, maar een tweede-orde taal over de geloofstaal. Verder maakt Lindbeck een onderscheid tussen "intrasystematische" en "ontologische" waarheid; de eerste is een vorm van 
coherentie, de tweede een vorm van correspondentie. Coherentie is de samenhang van geloofsuitspraken met heel de relevante context van de gelovige; niet alleen met andere uitspraken, maar ook met de levensvormen waarbinnen die uitspraken fungeren. Correspondentie is de overeenstemming van een levensvorm en de daarbinnen fungerende geloofsuitspraken met de ultieme werkelijkheid van God. In deze definities valt op dat uitspraken een functie zijn van de levensvorm en dat de waarheid van uitspraken eigenlijk de waarheid van hun levensvorm is. Dit roept de vraag op in welke zin geloofsuitspraken en leeruitspraken waar kunnen zijn.

Voor de waarheid van geloofsuitspraken is coherentie niet voldoende. Omdat geloofsuitspraken betrokken zijn op de werkelijkheid van God, is een vorm van correspondentie vereist. Deze correspondentie kunnen geloofsuitspraken volgens Linbeck alleen verkrijgen wanneer zij een levensvorm constitueren: "(...) a religious utterance, one might say, acquires the propositional truth of ontological correspondence only insofar as it is a performance, an act or deed, which helps create that correspondence" (Lindbeck 1984:65). Uit het feit dat leeruitspraken tweede-orde uitspraken zijn over de geloofstaal en geen eerste-orde uitspraken over de geloofde werkelijkheid leidt Lindbeck af dat zij, anders dan de geloofsuitspraken, slechts intrasystematisch waar kunnen zijn (waarheid als coherentie). In hun functie van leeruitspraak bezitten zij geen ontologische waarheidsclaim (waarheid als correspondentie) (Lindbeck 1984:69). Waarheid als correspondentie wordt alleen gesteld met en door de geloofsuitspraken.

In tegenstelling tot wat Van Veluw beweert (Van Veluw 2002:20) laat Lindbeck de aanspraak op waarheid als correspondentie dus niet vallen, en dit is een voordeel van zijn concept ten opzichte van dat van D Ritschl (Mildenberger 1991:268). Ik deel dan ook niet de vrees van C van der Kooi dat Lindbecks inzet "aan de meest fundamentele pretentie van het christelijk geloof" kan voorbijgaan, en gedoemd is "God nog slechts tussen aanhalingstekens te plaatsen" (Van der Kooi 2002:378). Wel is het zo, dat Lindbeck de vraag naar ontologische waarheid niet meer op het meta-niveau van de leer lokaliseert, maar op het primaire niveau 
van het geleefde geloof van de geloofs-gemeenschap waarbinnen geloofsuitspraken functioneren. De waarheid van geloofsuitspraken bestaat dan volgens hem in de coherentie en correspondentie tussen de gelovige levensvorm en de geloofde werkelijkheid. Omdat de waarheid van een geloofsuitspraak mede tot stand komt door de geloofsdaad van het uitspreken, is de waarheid van een geloofsuitspraak (mede) afhankelijk van de levenspraktijk van de gelovigen. Lindbeck geeft het volgende voorbeeld: "The crusader's battle cry 'Christus est Dominus', for example, is false when used to authorize cleaving the skull of the infidel (even though the same words in other contexts may be a true utterance)" (Lindbeck 1984:64). Lindbeck benadrukt echter dat, wanneer geloofsuitspraken op de juiste wijze worden gedaan, zij wel degelijk een waarheidsclaim maken.

There is nothing in the cultural-linguistic approach that requires the rejection (or the acceptance) of the epistemological realism and correspondence theory of truth, which, according to most of the theological tradition, is implicit in the conviction of believers that when they rightly use a sentence such as "Christ is Lord" they are uttering a true first-order proposition.

(Lindbeck 1984:68, 69)

\subsection{Vragen bij Lindbeck}

Deze visie op de geloofswaarheid roept tenminste drie vragen op. Kan de waarheid van een geloofsuitspraak als een vorm van correspondentie met een buitentalige werkelijkheid worden opgevat? Komt de waarheid van een geloofsuitspraak mede tot stand door de gelovige en is zij daarom van de levenspraktijk van de gelovige afhankelijk? Kan de waarheid van leeruitspraken uitsluitend intra-systematisch van aard zijn?

Volgens D Z Phillips kan de waarheid van de geloofstaal niet als een vorm van correspondentie worden beschouwen, omdat de werkelijkheid van het geloof niet onafhankelijk van de geloofstaal toegankelijk is (Phillips 1988:195-224). Wie dat toch doet, vat de geloofstaal ten onrecht op als een vorm van beschrijving. Tot de grammaticale regels van beschrijvende taal hoort echter volgens Phillips, dat men het voorwerp van de beschrijving kan aanwijzen, dat de inhoud van de 
beschrijvende predikaten bekend is en dat de geldigheid van de beschrijving objectief kan worden vastgesteld. Maar in de geloofstaal gelden andere regels. De uitspraak "Bush is momenteel president van de Verenigde Staten van Amerika" is daarom een beschrijving; uitspraken als "Christus is Heer" en "God is liefde" zijn dat volgens hem niet (Phillips 1988:202-205; 216-218). Phillips heeft natuurlijk gelijk waneer hij stelt dat wij God en de opgestane Christus niet op dezelfde manier kunnen beschrijven als fysieke objecten. Maar volgt daaruit dat geloofsuitspraken niet "ontologisch" waar kunnen zijn? Zijn alleen fysieke objecten werkelijk? (Van Holten 2003:111). Ook wanneer men de relatie tussen uitspraken en werkelijkheid niet langer opvat als een vorm van afbeelding (Brümmer 1995:173-176, 183), kan men volhouden dat geloofsuitspraken een constatieve functie hebben en er aanspraak op maken dat een stand van zaken inderdaad zo is als in deze uitspraken wordt verzekerd. "Religieus geloven is dan ook niet te reduceren tot een wijze van leven in tegenstelling tot het voor waar houden van bepaalde beweringen" (Brümmer 1995:210). De grammatica van het geloof sluit ontologische waarheid niet uit.

Lindbecks kan dus met recht stellen dat in geloofsuitspraken een claim op ontologische waarheid wordt gedaan en dat deze waarheid bestaat in een vorm van correspondentie (correspondentie hoeft nog geen vorm van afbeelding te zijn). Maar bestaat deze correspondentie primair tussen het gedrag van de gelovigen, waartoe ook hun taaldaden behoren, en de geloofde werkelijkheid en is de waarheid van geloofsuitspraken daarom afhankelijk van de gelovige levenspraktijk? Het kan worden betwijfeld dat de overeenstemming van ons levenspraktijk met de geloofde werkelijkheid een voldoende of zelfs noodzakelijke voorwaarde is voor de waarheid van geloofsuitspraken. Om te beginnen dienen we te bedenken, dat de waarheid van christelijke geloofs-uitspraken niet tot stand komt buiten de uitleg van de Schrift om. In de geloofstaal van de gemeente wordt immers de Schrift nagesproken. Dit punt is naar voren gebracht door Mildenberger, die daarmee feitelijk een aanvulling geeft op Lindbeck: "Nicht die Regeln sind (...) die Glaubenswahrheit, sondern diese Wahrheit realisiert sich dort, wo in der Auslegung der Bibel die Glaubenden hineingenommen sind in die 
Wirklichkeit, die die Bibel bezeugt" (Mildenberger 1991:268). De waarheid van geloofsuitspraken is mede afhankelijk van overeenstemming met de Schrift (Hunsinger 1991:172). Daarom is de overeenstemming met de levenspraktijk geen voldoende voorwaarde voor de waarheid van een geloofsuitspraak. Het kan zelfs worden betwijfeld of een passende levenspraktijk een noodzakelijke voorwaarde voor waarheid is. Hunsinger heeft vanuit Barths openbaringstheologie een kritische analyse gewijd aan Lindbecks beschouwing over de onwaarheid van de uitspraak "Christus is Heer" in de mond van een kruisvaarder die een ongelovige doodt (Hunsinger 1991:165-173). De context van deze uitspraak is volgens hem veel omvattender dan de geloofspraktijk van deze gelovige en zijn geloofsgemeenschap. Daarom kan deze uitspraak waar zijn ondanks het gedrag van degene die hem doet: "Even in a situation of abuse as illustrated by the skull-cleaving crusader, the total relevant context would be so established by the pattern of divine activity as mediated by scripture and proclaimed by the church that Christus est Dominus would retain a margin of truth over the abuse to which it was put, standing in real though implicit condemnation over the act of abuse itself (cf I/1, 110-11, 154)" (Hunsinger 1991:171). De waarheid van geloofsuitspraken is in deze optiek niet primair afhankelijk van het gedrag van de gelovigen, maar van het gebruik dat God van deze uitspraken maakt, desnoods tegen het gedrag van de gelovigen in. Daarom is de levenswandel van de gelovigen geen noodzakelijke voorwaarde van de waarheid van geloofsuitspraken.

Lindbecks nadruk op de levenspraktijk die geloofsuitspraken waar of onwaar maakt, miskent het onderscheid tussen de expressieve en constatieve functie van geloofsuitspraken. Met de begrippen "waar" en "onwaar" wordt de constatieve functie van uitspraken beoordeeld, de expressieve functie wordt beoordeeld met de begrippen "waarachtig" en "onwaarachtig" (Brümmer 1995:27, 182). Lindbeck reduceert de waarheid van geloofsuitspraken tot waarachtigheid. Zijn visie op de verhouding tussen geloofsuitspraken en leeruitspraken laat wel ruimte voor de ontologische waarheid van geloofsuitspraken, maar zijn uitwerking van de notie van de correspondentie in de geloofstaal schiet tekort. 
De derde vraag die zijn visie op waarheid oproept, betreft zijn stelling dat de waarheid van leeruitspraken niet ontologisch kan zijn, maar alleen intrasystematisch. Uit de stelling dat leeruitspraken in de systematische theologie doorgaans fungeren als tweede-orde uitspraken over de geloofstaal, volgt echter niet dat de waarheid van de leer uitsluitend intrasystematisch van aard kan zijn. Men kan ervoor kiezen leeruitspraken uitsluitend als tweede-orde uitspraken te beschouwen. Maar het is niet uitgesloten dat een leeruitspraak die systematisch fungeert als tweede-orde uitspraak over geloofsuitspraken, tegelijkertijd een ontologische waarheidsclaim bevat. Volgens Hart is dit feitelijk het geval bij Barth (Hart 1999:124). Ook Noordmans gaat uit van deze dubbele functie van leeruitspraken. Wanneer Noordmans de notie van het dogma als spreekregel introduceert in de inleiding van Herschepping (1934 !) (Noordmans 1979:216224), gaat hij uit van de verkondigende toespraak. Kerkelijke verkondiging geschiedt volgens de regels die gelden binnen de gemeenschap van de kerk en deze spreekregels zijn te onderscheiden van de soort regels die gelden in een wetenschappelijk betoog. Het geheel van deze regels noemt hij een grammatica of spraakkunst. In tegenstelling tot de regels van de retorica hebben deze regels betrekking op de inhoud. Juist als inhoudelijke regels willen zij de toespraak reguleren. Dat deze regulatieve functie bij Noordmans een tweede-ordekarakter heeft, blijkt uit uitspraken als: "Wij spreken telkens over een woord Gods, naar de regel der kerk" (Noordmans 1979:221), en: "De leer der Drie-eenheid kunnen wij niet preken, evenmin als enig ander dogma. Ze is een regel voor onze toespraak. Ze zet de verkondiger van het Evangelie midden in de bijbel, tussen profeten en apostelen en onder kerkvaders en reformatoren, en zegt dan tot hem: spreek nu maar zoals je wilt" (Noordmans 1979:224). Een historische onderbouwing van zijn visie geeft Noordmans in Het kerkelijk dogma (1934) (Noordmans 1979:173180). In tegenstelling tot de oosterse kerk waar het dogma vooral symbool bleef, ging het in het Westen fungeren ten dienste van het spreken en denken van de kerk. In de reformatie gaat het dogma vervolgens fungeren in het leven van de gemeente, de dogmatiek wordt pastoraal. Noordmans tekent deze ontwikkeling als een toenemende functionalisering. We zouden kunnen zeggen dat de 
leeruitspraken van de Griekse kerk met hun ontologische waarheidclaim steeds meer zijn gaan functioneren als regel voor het geloof van de geloofsgemeenschap. Bij Van Ruler vinden we dezelfde visie op het dogma als spreekregel voor de verkondiging als bij Noordmans. "De belijdenis, het dogma, is de grammatica van de taal des Geestes" (Van Ruler 1973:93). "Het dogma kan niet gepredikt worden" (Van Ruler 1973:95). Hij beargumenteert deze stellingen vanuit zijn visie op de verkondiging als profetie; de kerk "... moet de levende taal des Geestes spreken, puttend uit de volheid van de Heilige Schrift en handelende over alle dingen der totale existentie" (Van Ruler 1973:94).

\subsection{Conclusie}

Samenvattend kunnen we stellen dat in Lindbecks concept de vraag naar de ontologische waarheid van geloofsuitspraken niet vervalt. Wel wordt de waarheid van geloofsuitspraken door Lindbeck ten onrechte gereduceerd tot waarachtigheid. Ons gedrag kan wel in strijd zijn met onze geloofsuitspraken en onze geloofsovertuiging kan onwaarachtig zijn, maar onze geloofsuitspraken worden niet door ons gedrag waar of onwaar gemaakt. Verder zijn er geen dwingende redenen om de vraag naar ontologische waarheid uitsluitend bij geloofsuitspraken en niet bij leeruitspraken te stellen. Daarom kan de vraag naar ontologische waarheid van het christelijk geloof niet a priori buiten de systematische theologie gehouden worden. Zoals het werk van Pannenberg bewijst, is het zelfs mogelijk deze vraag in de systematische theologie expliciet aan de orde te stellen. Deze kritiek op Lindbecks uitwerking van de geloofswaarheid ontkracht echter niet zijn visie op de regulative functie van leeruitspraken. Ook wanneer geloofsuitspraken meer zijn dan uitdrukking van een geloofsovertuiging en ook wanneer leeruitspraken een ontologische waarheidsclaim maken, kunnen leeruitspraken als regel voor geloofsuitspraken fungeren, zoals blijkt bij Barth, Noordmans en Van Ruler.

We stelden de vraag: kunnen regels waar zijn; kunnen ware uitspraken regels zijn? De vraag is onnauwkeurig gesteld. De vraag moet zijn: kunnen uitspraken tegelijk als regel en als bewering functioneren. Het antwoord kan nu 
als volgt luiden. Geloofsuitspraken zijn geen regels; maken aanspraak op ontologische waarheid. Leeruitspraken kunnen aanspraak maken op ontologische waarheid zonder de geloofsuitspraken te reguleren; zij kunnen aanspraak maken op ontologische waarheid en tegelijk functioneren als spreekregel voor de geloofstaal; en zij kunnen tenslotte puur als regel functioneren zonder aanspraak op ontologische waarheid.

\section{BESLUIT: TEGENWOORDIGHEID VAN GEEST}

Wanneer wij het dogma beschouwen en hanteren als spreekregel, worden verschillende dingen goed duidelijk. Om te beginnen het verschil tussen Schrift en dogma: de Schrift hoort tot het vaste vocabulaire van de geloofstaal, het dogma tot de grammatica. Dogma's vervullen in de kerk een heel andere functie dan de verstaanbare verkondiging van de Schrift, het actuele belijden van de gemeente en de communicatie van het geloof. Als spreekregel is het dogma geen filosofische speculatie over goddelijke zaken, maar gericht op de praktijk van het geloofsleven: het helpt ons christelijk te spreken over God en dit spreken kan niet worden losgemaakt van het christelijk leven voor Gods aangezicht. Het blijft intussen wel een hele kunst om volgens deze regels te spreken. Niet voor niets noemen wij een grammatica een spraakkunst. Tot deze kunst behoort dat je aanvoelt wat je over God kunt zeggen en wat niet, en wanneer je dat doet en wanneer niet, en hoe je dat doet en hoe niet. Dit besef hebben wij niet helemaal zelf in de hand, want het is tegenwoordigheid van Geest.

\section{Literatuurverwysings}

Augustinus. De doctrina christiana.

Barth, K 1960. Kirchliche Dogmatik, I/2. 5.Aufl. Zürich: Evangelischer Verlag.

Brümmer, V 1995. Wijsgerige Begripsanalyse: Een inleiding voor theologen en andere belangstellenden. $4^{\mathrm{e}} \mathrm{dr}$. Kok: Kampen.

Calvijn, J 1928. Opera selecta, vol III. Barth, P \& Niesel, W (Hrsg). München: Kaiser. Dalferth, I U 1993. Jenseits von Mythos und Logos: Die christologische Transformation der Theologie. Freiburg-Basel-Wenen: Herder. (Questiones Disputatae 142.) Gloege, G 1958. s v Dogma, II. RGG. 3. Aufl. 
Hart, T A 1999. Regarding Karl Barth: Essays towards a reading of his theology. Carlisle: Paternoster.

Hauschild, W D 1995. Lehrbuch der Kirchen- und Dogmengeschichte: 1 Alte Kirche und Mittelalter. Gütersloh: Gütersloher Verlagshaus.

Hunsinger, G 1991. How to read Karl Barth: The shape of his theology. New York: Oxford University Press.

James, P D 2002. Death in holy orders. London: Penguin.

Kasper, W 1995. Der Gott Jesu Christi. 3.Aufl. Mainz: Grünewald.

Kelly, J N D 1999. Early Christian creeds. $3^{\text {rd }}$ ed. New York: Longman.

Kelly, J N D 2000. Early Christian doctrines. $4^{\text {rd }}$ ed. New York: Continuum.

Koopmans, J 1955. Das altkirchliche Dogma in der Reformation. München: Kaiser.

(Beiträge zur evangelischen Theologie 22.)

Lindbeck, G A 1984. The nature of doctrine: Religion and theology in a postliberal age. Philadelphia: Westminster.

Lohse, B 1974, Epochen der Dogmengeschichte. 3. Aufl. Stuttgart: Kreuz.

Loofs, F 1906. Leitfaden der Dogmengeschichte. 4. Aufl. Halle: Niemeyer.

McGrath, A E 1997. The genesis of doctrine: A study in the foundations of doctrinal criticism. Grand Rapids: Eerdmans.

Mildenberger, F 1991. Biblische Dogmatik: Eine biblische Theologie in dogmatischer Perspektive, Bd. 1: Prolegomena. Verstehen und Geltung der Bibel. Stuttgart: Kohlhamer.

Müller, E F K (Hrsg) 1903. Die Bekenntnisschriften der reformierten Kirche. Leipzig. Nederlandse Hervormde Kerk. Generale Synode 1955. Dienstboek voor de Nederlandse Hervormde Kerk in ontwerp. 's Gravenhage: Boekencentrum.

Noordmans, O 1979. Verzamelde Werken, II. Kampen: Kok.

Opitz, P 1994. Calvins theologische Hermeneutik. Neukirchen-Vluyn: Neukirchener.

Phillips, D Z 1988. Faith after foundationalism. London: Routledge.

Ritschl, D 1984. Zur Logik der Theologie: Kurze Darstellung der Zusammenhänge theologischer Grundgedanken. München: Kaiser.

Van der Kooi, C 2002. Als in een spiegel: God kennen volgens Calvijn en Barth. Kampen: Kok

Van Holten, W 2003. Explanation within the bounds of religion. Frankfurt am Main: Peter Lang. (Contributions to Philosophical Theology 9.)

Van Ruler, A A 1973. Hoe functioneert de belijdenis? Nijkerk: Callenbach. (Theologisch Werk VI.)

Van Veluw, A H 2002. "De straf die ons de vrede aanbrengt": Over God, kruis, straf en slachtoffers van deze wereld in de christelijke verzoeningsleer. Zoetermeer: Boekencentrum.

Wansink, P L 2000. Irenaeus en het Oude Testament: Gnostische en heilshistorische exegese in de tweede eeuw. Zoetermeer: Boekencentrum. 